\title{
ANALISA KESTABILAN MODEL PENYEBARAN PENYAKIT RABIES
}

(The Analysis of Model Stability for the Spread of Rabies Disease)

\author{
FRANCIS Y. RUMLAWANG ${ }^{1}$, MARIO IVAN NANLOHY ${ }^{2}$ \\ ${ }^{1}$ Staf Jurusan Matematika, FMIPA, Unpatti \\ ${ }^{2}$ Alumni Jurusan Matematika, FMIPA Unpatti \\ J1. Ir. M. Putuhena, Kampus Unpatti, Poka-Ambon \\ e-mail: rumlawang@yahoo.com
}

\begin{abstract}
Rabies is a dangerous disease that can cause death due to rabies virus attacks the spinal cord of the infected and can cause paralysis. But if it enters the limbic system or midbrain, it will cause aggression and loss of sense. The widespread dissemination of this disease is growth increasingly. This research will discuss about the model of the spread rabies and then analyze stability of this model by using simple epidemiological model to determine the initial equilibrium point and eigenvalues, which would be analyzed the stability of this model. This model has two main variables $\boldsymbol{S}$ and $\boldsymbol{I}$, where $\boldsymbol{S}$ is the susceptible and $\boldsymbol{I}$ is the infectives. This research found the stability model at $(\mathbf{1}, \mathbf{0})$ equilibrium point with the value of $\boldsymbol{c}$ parameter is $c \geq 2 \sqrt{1-m}$.
\end{abstract}

Keywords: Eigenvalues, Equilibrium point, Jacobian-matrix, Rabies, SIR-models.

\section{PENDAHULUAN}

Rabies bukanlah penyakit baru dalam sejarah peradaban manusia. Catatan tertulis mengenai perilaku anjing yang tiba-tiba menjadi buas ditemukan pada kode Mesopotamia yang ditulis 4000 tahun lalu serta pada kode Babilonia Eshunna yang ditulis pada 2300 SM. Democritus pada 500 SM juga menuliskan karakteristik gejala penyakit yang menyerupai rabies. Goldwasser dan Kissling menemukan cara diagnosis rabies secara modern pada tahun 1958, yaitu dengan teknik antibodi imunofluoresens untuk menemukan antigen rabies pada jaringan. Secara etimologi, kata rabies berasal dari bahasa Sansekerta kuno rabhas yang artinya melakukan kekerasan atau kejahatan. Dalam bahasa Yunani, rabies disebut Lyssa atau Lytaa yang artinya kegilaan dan dalam bahasa Prancis, rabies disebut rage berasal dari kata benda robere yang artinya menjadi gila.

Rabies sendiri di Indonesia sudah lama ditemukan dan hampir semua daerah tertular virus. Rabies pertama kali ditemukan pada kerbau oleh Esser (1884), anjing oleh Penning (1889), dan pada manusia oleh E.V.de Haan (1894) yang ketiganya ditemukan di Jawa Barat. Rabies di Indonesia merupakan masalah kesehatan masyarakat yang serius karena hampir selalu menyebabkan kematian (always almost fatal) setelah timbul gejala klinis dengan tingkat kematian sampai $100 \%$.
Solusi pencegahan, pemberantasan, dan penyebaran penyakit rabies telah banyak dilakukan dan dikaji dari sisi kesehatan. Salah satu disiplin ilmu yang bisa membantu mengatasi permasalahan tersebut adalah matematika. Pemodelan matematika dapat dimanfaatkan untuk menyelesaikan masalah penyebaran penyakit rabies dengan menggunakan asumsi-asumsi tertentu yang solusinya dapat diperoleh baik secara analitis maupun numerik.

Model SIR (Susceptible, Infectives, Recovered) pada awalnya dikembangkan untuk mengetahui laju penyebaran dan kepunahan suatu penyakit dalam populasi tertutup dan bersifat epidemik. Selanjutnya dari model yang sudah ada akan dianalisa kestabilannya.

Tujuan dari penelitian ini adalah menjelaskan model penyebaran penyakit rabies dan menganalisa kestabilan model penyebaran penyakit rabies.

\section{TINJAUAN PUSTAKA}

Sebelum masuk ke model matematika, akan dilihat sedikit tentang rabies itu sendiri. Dalam tulisannya pada Natural History of Animals edisi 8, Aristotle (400 SM) menulis, "Anjing itu menjadi gila. Hal ini menyebabkan mereka menjadi agresif dan semua binatang yang digigitnya juga mengalami sakit yang sama”. 
Rabies disebabkan oleh virus rabies yang masuk ke keluarga Rhabdoviridae dan genus Lysavirus. Karakteristik utama virus adalah hanya memiliki satu utas negatif RNA yang tidak bersegmen. Virus ini hidup pada beberapa jenis hewan yang berperan sebagai perantara penularan antara lain rakun, rubah merah, anjing dan lain-lain. Hewan perantara menginfeksi inang yang bisa berupa hewan lain atau manusia melalui gigitan. (Madigan MT, Martinko JM, Dunlap PV, Clark DP 2009).

Rabies adalah virus mengerikan yang menyerang sistem saraf utama. Semua hewan berdarah panas dapat terinfeksi rabies (Twisleton-Wykeham-Fiennes, 1987).

Penyebaran rabies spasial merupakan sebuah proses yang kompleks. Salah satu pendekatan untuk memodelkan penyebarannya adalah memulai dengan model epidemiologi sederhana untuk melihat peningkatan penyebarannya (Kallen et al., 1985; Murray et al., 1986).

Selain itu juga teori kestabilan berikut sangat diperlukan dalam menganalisa kestabilan dari model yang sudah ada.

Diberikan sistem persamaan linier

$$
\begin{gathered}
\frac{d x_{1}}{d t}=f_{1\left(x_{1}, x_{2} \ldots, x_{n}\right)} \\
\vdots \\
\frac{d x_{n}}{d t}=f_{n\left(x_{1}, x_{2} \ldots, x_{n}\right)}
\end{gathered}
$$

dengan kondisi awal $x_{t_{0}}\left(t_{0}\right)=x_{i}, i=1,2, \ldots, n$.

Sistem (1) dapat ditulis sebagai

$$
\frac{d x}{d t}=f(x)
$$

dengan

$$
\frac{d x}{d t}=\left(x_{1}, x_{2} \ldots, x_{n}\right)^{T} \in \mathbb{R}^{n},
$$

$f(x)=\left(f_{1}(x), f_{2}(x), \ldots, f_{n}(x)\right)^{T} \in \mathbb{R}^{n}$ dan memenuhi kondisi awal $x\left(t_{0}\right)=\left(x_{01}, x_{02}, \ldots, x_{0 n}\right)^{T}$. Selanjutnya notasi $x_{t}=x\left(x_{0}, t\right)$ menyatakan solusi sistem (1) di atas yang melalui $x_{0}$.

Diberikan sistem persamaan diferensial non linear

$$
\frac{d x}{d t}=f(x)
$$

dengan $f$ adalah fungsi non linear dan kontinu, $f: E \rightarrow$ $\mathbb{R}^{n}, E \subset \mathbb{R}^{n}$.

Perilaku solusi pada persekitaran titik kesetimbangan sistem non linear pada Persamaan (2) dapat ditentukan setelah dilakukan pelinieran pada persekitaran titik kesetimbangan sistem.

\section{Definisi 1}

Sistem $\frac{d x}{d t}=J(f(\bar{x})) x$ disebut linearisasi sistem (2) di $\bar{x}$.

Definisi 2 (Titik Kesetimbangan)

Titik $\quad x \in \mathbb{R}^{n}$ disebut titik kesetimbangan (titik equilibrium) sistem jika $f(x)=0$.

Definisi 3 (Titik Kesetimbangan)

1. Titik kesetimbangan $\underline{x}$ dikatakan stabil jika untuk setiap bilangan $\varepsilon>0$ terdapat bilangan $\delta>0$ sedemikian hingga untuk setiap solusi $y(t)$ yang memenuhi $\left|y\left(t_{0}\right)-\underline{x}\right|<\delta$ berlaku $|x(t)-\underline{x}|<\varepsilon$ untuk $t \geq t_{0}$.
2. Titik kesetimbangan $\underline{x}$ dikatakan stabil asimtotik jika $\underline{x}$ stabil dan terdapat bilangan $\delta_{0}>0$ sedemikian hingga untuk setiap setiap solusi $y(t)$ yang memenuhi $\left|y\left(t_{0}\right)-\underline{x}\right|<\delta_{0}$ berlaku $|y(t)-\underline{x}| \rightarrow 0$ untuk $t \rightarrow$ $\infty$.

Dengan melakukan pelinearan terhadap sistem yakni melalui ekspansi Taylor di sekitar titik tetap $\underline{x}$ diperoleh matriks Jacobian untuk sistem (2) sebagai berikut:

$$
J=\left[\begin{array}{ll}
\frac{\partial f_{1}}{\partial x} & \frac{\partial f_{1}}{\partial y} \\
\frac{\partial f_{2}}{\partial x} & \frac{\partial f_{2}}{\partial y}
\end{array}\right]
$$

Perilaku dinamik untuk sistem dapat diidentifikasi secara lengkap oleh nilai eigen dari matriks $J$, yaitu:

$$
\begin{aligned}
& \left|\begin{array}{cc}
\lambda-\frac{\partial f_{1}}{\partial x} & -\frac{\partial f_{1}}{\partial y} \\
-\frac{\partial f_{2}}{\partial x} & \lambda-\frac{\partial f_{2}}{\partial y}
\end{array}\right| \\
& =\left(\lambda-\frac{\partial f_{1}}{\partial x}\right)\left(\lambda-\frac{\partial f_{2}}{\partial y}\right)-\left(-\frac{\partial f_{2}}{\partial x}\right)\left(-\frac{\partial f_{1}}{\partial y}\right)=0 \\
& \lambda^{2}-\left(\frac{\partial f_{1}}{\partial x}+\frac{\partial f_{2}}{\partial y}\right) \lambda+\left(\frac{\partial f_{1}}{\partial x} \frac{\partial f_{2}}{\partial y}-\frac{\partial f_{2}}{\partial x} \frac{\partial f_{1}}{\partial y}\right)=0 \\
& \lambda^{2}-\operatorname{Tr}(J) \lambda+\operatorname{Det}(J)=0
\end{aligned}
$$

Dengan demikian berdasarkan kajian terhadap nilai eigen $\lambda_{1}$ dan $\lambda_{2}$ jenis kestabilan dari sistem adalah sebagai berikut:

a. $\lambda_{1}<0$ dan $\lambda_{2}<0$, maka disebut simpul stabil

b. $\lambda_{1}>0$ dan $\lambda_{2}>0$, maka disebut simpul tidak stabil

c. $\lambda_{1}$ dan $\lambda_{2}$ kompleks dengan bagian real negatif maka dikatakan fokus stabil.

d. $\lambda_{1}$ dan $\lambda_{2}$ kompleks dengan bagian real positif maka disebut fokus tidak stabil.

e. $\lambda_{1}$ dan $\lambda_{2}$ real tapi satunya negatif dan lainnya positif maka disebut titik sadel.

f. $\lambda_{1}$ dan $\lambda_{2}$ kompleks murni maka disebut pusat.

Jenis kestabilan dalam bidang fase dapat dilihat pada Gambar 1 berikut ini

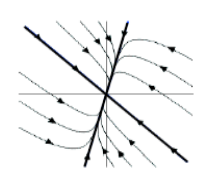

(a)

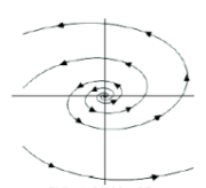

(d)

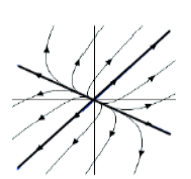

(b)

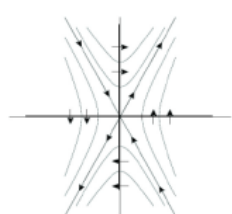

(e)

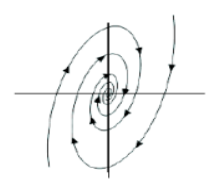

(c)

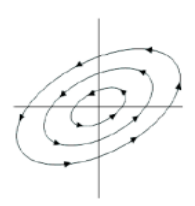

(f)
Gambar 1. Jenis kestabilan dalam bidang fase 


\section{HASIL DAN PEMBAHASAN}

\section{Model Penyebaran Penyakit Rabies}

Penyebaran penyakit rabies sudah banyak diteliti. Penyebaran spasial penyakir rabies merupakan sebuah proses yang kompleks. Oleh karena itu berdasarkan Kallen dan Murray yang menyatakan bahwa salah satu pendekatan untuk memodelkan penyebaran penyakit rabies adalah memulai dengan model epidemiologi sederhana untuk melihat peningkatan penyebarannya setelah itu akan dianalisis kestabilan dari model tersebut.

Dari model SIR, hanya akan digunakan dua variabel untuk model penyebaran rabies. Diperkirakan dua kelompok objek rabies, kelompok pertama yaitu, Susceptible $(S)$ atau objek yang rentan terserang rabies, dan kelompok yang kedua yaitu, Infective (I) atau objek yang terinfeksi rabies. Objek yang terinfeksi berinteraksi dengan objek yang rentan, dan kemudian menjangkitkan rabies. Asumsi umum dari model yang akan digunakan ialah migrasi dari objek yang terinfeksi menentukan kondisi perubahan epidemi ke depan.

Ada beberapa asumsi khusus yang mendasari model ini. Asumsi-asumsi tersebut adalah :

(i). Virus rabies terdapat dalam air liur dari objek yang terinfeksi dan biasanya ditularkan oleh gigitan. Oleh karena itu kontak antara objek yang terinfeksi dan objek yang rentan diperlukan untuk penularan penyakit.

(ii). Rabies adalah selalu fatal.

(iii). Laju kelahiran sama dengan laju kematian.

(iv). Terdapat kontak yang tetap antara objek yang rentan dan objek yang terinfeksi dalam populasi.

(v). Perubahan waktu dari jumlah objek yang terinfeksi pada sebuah wilayah yang kecil adalah sama dengan rata-rata waktu peralihan dari jumlah populasi objek yang rentan dikurangi rata-rata tingkat kematian dan jumlah migrasi dari wilayah tersebut.

(vi). Interval waktu yang pendek diasumsikan kurang dari satu tahun.

(vii). Jika virus rabies memasuki sumsum tulang belakang dari objek yang terinfeksi, maka hal ini dapat menyebabkan kelumpuhan. Namun jika memasuki sistem limbik atau otak tengah yang posisinya sedikit lebih ke depan dan terdiri atas Talamus dan Ganglia Basal, maka mungkin akan menyebabkan agresi dan hilangnya rasa.

Penjelasan untuk asumsi khusus yang terakhir, sistem limbik terdiri dari hipotalamus dan amigdala yang berfungsi penting bagi pembelajaran dan ingatan jangka pendek tetapi juga menjaga homeostatis di dalam tubuh (tekanan darah, suhu tubuh dan kadar gula darah). Sistem limbik terlibat dalam emosi ketahanan hidup dari hasrat seksual atau perlindungan diri. Akibatnya, objek yang terinfeksi, bisa berkeliaran secara acak dan tidak terkendali.

Dengan demikian, manusia juga termasuk dalam objek yang rentan untuk terinfeksi rabies. Sementara itu perubahan dari jumlah populasi objek yang rentan cukup sederhana yaitu dengan menghitung angka kematian dari populasi objek yang sudah terinfeksi rabies.

Model awal yang akan digunakan dan dianalisa kestabilannya dalam penelitian ini adalah sebagai berikut:

$$
\begin{gathered}
\frac{\partial S}{\partial t}=-r S I \\
\frac{\partial I}{\partial t}=r S I-a I+D \frac{\partial^{2} I}{\partial x^{2}}
\end{gathered}
$$

dengan,

$S \quad$ : Objek yang rentan terserang rabies

$I \quad$ : Objek yang telah terinfeksi rabies

$r \quad$ : Koefisien penyebaran rabies

$a$ : Peluang objek terinfeksi dapat bertahan

$D$ : Koefisien penyebaran pada wilayah epidemi

Untuk koefisien penyebaran $D$ dapat diperkirakan menggunakan persamaan,

$$
D=k A
$$

dengan,

$k$ : Tetapan pada saat objek yang terinfeksi meninggalkan wilayah epidemi

$A$ : Rata-rata luas wilayah

Dari penjelasan ini, diperoleh nilai $\frac{1}{k}$ adalah rata-rata waktu sampai objek yang terinfeksi rabies meninggalkan wilayah epidemi. Tetapi perkiraan yang lebih akurat untuk nilai $D$ bisa diperoleh dengan observasi langsung di lapangan dengan menghitung jarak perjalanan dari objek yang terinfeksi selama periode waktu observasi.

Parameter pada Persamaan (3a) dan (3b) dapat dinondimensikan. Jika diberikan,

$$
\begin{gathered}
\tilde{I} \equiv \frac{I}{S_{0}}, \tilde{S} \equiv \frac{S}{S_{0}}, \\
\tilde{x} \equiv \sqrt{\frac{r S_{0}}{\mathrm{D}}} x, \quad \tilde{t} \equiv r S_{0} t, \quad m \equiv \frac{a}{r S_{0}}
\end{gathered}
$$

Dengan $S_{0}$ adalah nilai awal dari objek yang rentan dengan tetapan nilainya adalah 1 . Kemudian dengan mengabaikan tanda tilda pada persamaan untuk penyederhanaan notasi akhirnya diperoleh,

$$
\begin{gathered}
\frac{\partial S}{\partial t}=-S I \\
\frac{\partial I}{\partial t}=I(S-m)+\frac{\partial^{2} I}{\partial x^{2}}
\end{gathered}
$$

Kemudian akan dicari solusi pergerakan gelombang untuk sistem ini dalam bentuk,

$$
\begin{gathered}
S(x, t)=S(x-c t) \equiv S(z) \\
I(x, t)=I(x-c t) \equiv I(z)
\end{gathered}
$$

Maka diperoleh dua persamaan diferensial biasa

$$
\begin{gathered}
c S^{\prime}=I S, \\
I^{\prime \prime}+c I^{\prime}+(S-m) I=0
\end{gathered}
$$

Untuk mengantisipasi pergerakan di depan dua gelombang $S$ dan $I$ yang berjalan, maka diberikan kondisi batas,

$$
S(+\infty)=1, \quad I(+\infty)=0
$$

Di samping itu, diberikan juga kondisi batas untuk objek yang rentan sebagai berikut

$$
S(-\infty)=0, \quad I(-\infty)=0
$$

Jika Persamaan (4a) disubstitusikan ke Persamaan (4b), maka diperoleh

$$
I^{\prime \prime}+c I^{\prime}+\frac{c S^{\prime}(S-m)}{S}=0
$$


Kemudian diintegralkan sehingga hasil yang didapatkan adalah,

$$
\begin{aligned}
& \int I^{\prime \prime}(S)+c I^{\prime}(S)+\frac{c S^{\prime}(S-m)}{S} d S=\int 0 d S \\
& I^{\prime}+c I+c S-c m \ln S=k \text { (konstan) }
\end{aligned}
$$

Dengan menggunakan pendekatan kondisi batas $Z$ tak hingga di atas dapat disimpulkan bahwa Persamaan (6) akan konstan jika nilai $k$ hanya sama dengan c. Sehingga Persamaan (6) menjadi,

$$
I^{\prime}+c I+c S-c m \ln S=c
$$

Ini berarti bahwa tidak ada objek terinfeksi sebelum epidemi. Setelah epidemi, ada peluang bahwa akan ada objek rentan yang terinfeksi (karena rabies hampir selalu fatal).

Sekarang dengan pendekatan $z$ negatif pada kondisi batas yang sudah ditentukan maka Persamaan (7) menjadi,

atau

$$
S(-\infty)-m \ln S(-\infty)=1
$$

$$
\frac{S(-\infty)-1}{\ln S(-\infty)}=m=\frac{a}{r S_{0}}
$$

Hal ini memungkinkan bagian populasi dari objek yang rentan dapat ditentukan. Pada Gambar 4 terlihat bahwa hubungan antara parameter $m$ dan nilai dari objek yang rentan dimulai dengan nilai $m=0$ kemudian naik dan berbanding lurus dengan pergerakan objek yang rentan sampai di titik $(1,1)$. Hal ini memberikan pengertian bahwa proses epidemi telah terjadi.

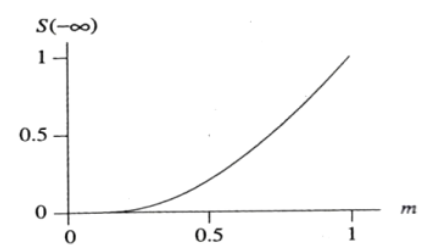

Gambar 2. Grafik fungsi dari parameter $m$

Parameter $m$ adalah ukuran dari tingkat kondisi objek epidemi, dengan nilai yang lebih rendah menandakan objek yang rentan berpeluang hidup.

Untuk terjadinya epidemi, diperlukan nilai $m<1$. Jika $m>1$, sehingga $a>r S_{0}$, angka kematian pada objek yang terinfeksi lebih besar dari tingkat terbentuknya objek terinfeksi yang baru dan objek yang terinfeksi rabies tidak akan dapat bertahan. Nilai $m=1$ juga memberikan titik kritis objek rentan, $S_{0}=\frac{a}{r}$, yang menjadi syarat terjadinya epidemi.

\section{Titik Kesetimbangan}

Persamaan (4a) dan (7) digabungkan, kemudian akan dicari titik kesetimbangannya dengan menggunakan Definisi 2 dan Definisi 3 tentang titik kesetimbangan.

$$
\begin{gathered}
S^{\prime}=\frac{1}{c} S I, \\
I^{\prime}=-c(S+I)+c m \ln S+c
\end{gathered}
$$

Sistem (8a) dan (8b) dapat dianalisis dengan cara biasa.

Pertumbuhan awal objek yang rentan diberikan oleh

$$
S=0
$$

dan

$$
I=0
$$

Sedangkan pertumbuhan awal objek yang terinfeksi diberikan oleh

$$
I=m \ln S-S+1
$$

Dari Persamaan (8a) dan (8b) didiferensialkan masing-masing terhadap $S$ dan $I$ sebagai berikut,

maka diperoleh,

$$
S^{\prime}=f(x)=\frac{1}{c} S I
$$

kemudian,

$$
\frac{\partial f}{\partial S}=\frac{I}{c} \text { dan } \frac{\partial f}{\partial I}=\frac{S}{c}
$$

$$
I^{\prime}=g(x)=-c(S+I)+c m \ln S+c
$$

maka diperoleh,

$$
\frac{\partial g}{\partial S}=-c+\frac{c m}{S} \text { dan } \frac{\partial g}{\partial I}=-c
$$

Sehingga matriks Jacobian yang dibentuk adalah sebagai berikut,

$$
\begin{gathered}
\boldsymbol{J}=\left(\begin{array}{ll}
\frac{\partial f}{\partial S} & \frac{\partial f}{\partial I} \\
\frac{\partial g}{\partial S} & \frac{\partial g}{\partial I}
\end{array}\right) \\
J=\left(\begin{array}{cc}
\frac{I}{c} & \frac{S}{c} \\
-c+\frac{c m}{S} & -c
\end{array}\right)
\end{gathered}
$$

Dari Persamaan (8a) dan (8b) diperoleh dua kesetimbangan yang menarik. Salah satunya adalah di $[S(-\infty), 0]$ dan yang lainnya adalah di $(1,0)$

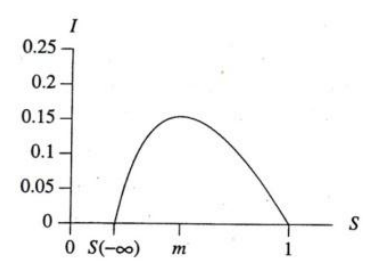

Gambar 3. Bidang fase $(S, I)$

Gambar 3 menunjukkan bidang fase dari $(S, I)$ yang dibentuk dari persamaan $I=m \ln S-S+1$, dimana titik-titik kritis dibentuk pada $[S(-\infty), 0]$ dan $(1,0)$. Kurva yang dibentuk dari kedua titik tersebut menunjukkan penyebaran penyakit menjadi epidemi dan mencapai puncak pada saat $m$ bernilai 0,5 , setelah itu akan menurun sampai pada titik $(1,0)$.

Selanjutnya, pada $[S(-\infty), 0]$, matriks Jacobian direduksi menjadi

$$
\boldsymbol{J}=\left(\begin{array}{cc}
0 & \frac{S(-\infty)}{c} \\
-c+\frac{c m}{S(-\infty)} & -c
\end{array}\right)
$$

Dari matriks Jacobian tersebut diperoleh persamaan karakteristik

$$
\lambda^{2}+c \lambda-[m-S(-\infty)]=0
$$

Persamaan karakteristik tersebut memiliki nilai eigen dengan tanda berlawanan atau titik $(S(-\infty), 0)$ memiliki kesetimbangan dengan bentuk saddle point. 

menjadi

Sedangkan pada $(1,0)$, matriks Jacobian direduksi

$$
\boldsymbol{J}=\left(\begin{array}{cc}
0 & \frac{1}{c} \\
c+(m-1) & -c
\end{array}\right)
$$

dari matriks Jacobian tersebut diperoleh persamaan karakteristik

$$
\lambda^{2}+c \lambda+(1-m)=0
$$

\section{Analisa Kestabilan Model Penyebaran Penyakit Rabies}

Berdasarkan hasil dari persamaan karakteristik untuk titik $(\mathbf{1}, \mathbf{0})$ di atas, maka dengan demikian diperoleh

$$
\lambda_{1,2}=\frac{-c \pm \sqrt{c^{2}-4(1-m)}}{2}
$$

Dari Persamaan (12) akan dianalisa kestabilannya. Akan diperhatikan terlebih dahulu nilai yang di bawah tanda akar yaitu,

$$
c^{2}-4(1-m)
$$

Untuk menghasilkan nilai $\lambda$ berupa bilangan kompleks, maka nilai $c^{2}-4(1-m)$ harus kurang dari nol.

$$
\begin{array}{r}
c^{2}<4(1-m) \quad c^{2}-4(1-m)<0 \\
c<2 \sqrt{(1-m)}
\end{array}
$$

Sehingga untuk $c<2 \sqrt{(1-m)}$, diperoleh nilai $\lambda_{1}$ dan $\lambda_{2}$ berupa bilangan kompleks dengan bagian riilnya sama-sama bernilai negatif.

$$
\lambda_{1,2}=-\frac{1}{2} c \pm \frac{1}{2} \sqrt{c^{2}-4(1-m)}
$$

Dari persamaan ini diketahui $-\frac{1}{2} c$ adalah bagian riil dan $\pm \frac{1}{2} \sqrt{c^{2}-4(1-m)}$ adalah bagian imajiner. Untuk nilai $\lambda_{1}$ dan $\lambda_{2}$ kompleks dengan bagian riil negatif, maka berdasarkan bagian 2.2.5 tentang teori kestabilan, kesetimbangan pada titik $(1,0)$ dapat dikatakan stable focus atau fokus stabil untuk nilai $c<2 \sqrt{(1-m)}$. Untuk kesetimbangan, ini tidak mungkin ada hubungan heteroklinik dengan jumlah nonnegatif dari infeksi.

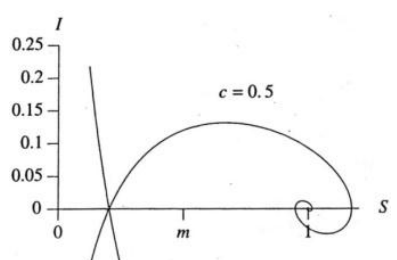

Gambar 4. Fokus stabil untuk $c<2 \sqrt{1-m}$

Gambar 6 memberikan hasil bentuk kestabilan yang diperoleh adalah fokus stabil, dengan menggunakan nilai parameter $c=0,5$. Kurva yang dibentuk menunjukkan model yang digunakan dengan nilai parameter $c<2 \sqrt{(1-m)}$ akan bergerak menuju titik $(1,0)$. Artinya penyebaran stabil jika menuju pusat $(1,0)$.

Kemudian yang berikutnya, untuk menghasilkan nilai $\lambda$ berupa bilangan riil, maka nilai $c^{2}-4(1-m)$ harus lebih dari nol.

$$
\begin{gathered}
c^{2}-4(1-m) \geq 0 \\
c^{2} \geq 4(1-m)
\end{gathered}
$$

$$
c \geq 2 \sqrt{(1-m)}
$$

Selanjutnya tinggal ditentukan nilai $\lambda_{1}$ dan $\lambda_{2}$ bernilai riil negatif atau riil positif.

Dari persamaan $\lambda_{1,2}=-\frac{1}{2} c \pm \frac{1}{2} \sqrt{c^{2}-4(1-m)}$ diketahui $-\frac{1}{2} c$ dinamakan bagian pertama dan $\pm \frac{1}{2} \sqrt{c^{2}-4(1-m)}$ dinamakan bagian kedua. Bagian pertama pasti lebih dari bagian kedua. Untuk nilai $c \geq 2 \sqrt{(1-m)}$ bernilai riil. Sehingga jika negatif bagian pertama dijumlahkan dengan bagian yang kedua, maka pasti bernilai negatif, dan jika negatif bagian pertama dikurangi dengan negatif bagian kedua, maka pasti akan bernilai negatif juga. Dengan demikian kestabilan pada titik kesetimbangan $(1,0)$ berdasarkan bagian 2.2.5 tentang teori kestabilan, diperoleh jenis kestabilannya adalah stable node atau simpul stabil. Oleh karena itu kesetimbangan di titik $(1,0)$ adalah stabil dan memiliki hubungan heteroklinik positif yang berarti penyebaran penyakit terjadi epidemi.

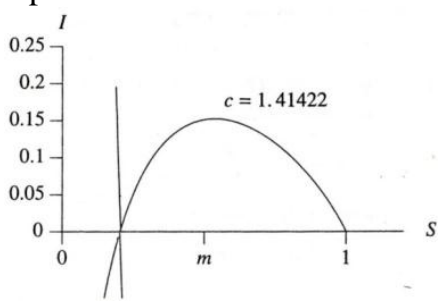

Gambar 5. Simpul stabil untuk $c \geq 2 \sqrt{1-m}$

Gambar 5 memberikan pola kurva penyebaran yang membentuk simpul stabil dan berujung pada titik $(1,0)$. Garis lurus sejajar sumbu $I$, menunjukkan kondisi populasi yang belum terinfeksi. Arah penyebarannya juga sesuai dengan epidemi yang mencapai puncak pada saat nilai $m=0.5$ sehingga nilai parameter $c$ yang diperoleh dari gambar tersebut adalah $c=1,41422$. Hal ini memberikan kecepatan gelombang minimum untuk pergerakan gelombang $S$ dan $I$ yang berjalan.

Analisa dari model penyebaran rabies memiliki populasi objek yang rentan monoton menurun pada saat epidemi dan puncak tunggal pada objek yang terinfeksi terjadi pada saat epidemi.

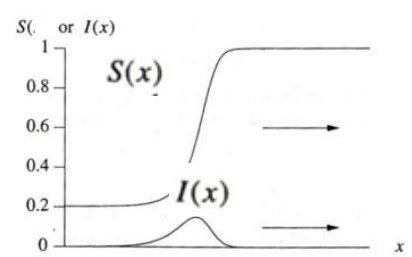

Gambar 6. Pergerakan gelombang model rabies

Sebaliknya Gambar 6 menunjukkan pergerakan pada jumlah objek yang terinfeksi $I(x)$ yang ditunjukan oleh garis gelombang yang dibawah dan objek yang rentan $S(x)$ ditunjukkan oleh garis gelombang yang di atas, membelakangi pergerakan gelombang yang berjalan kemudian dalam penelitian ini merupakan penyebaran rabies itu sendiri. Setelah bagian yang membelakangi gelombang maka bagian depan gelombang merupakan populasi dari objek yang rentan dan akan mulai meningkat lagi. Hal ini berakibat, Persamaan (3a) dan 
(3b) dapat dijadikan acuan sebagai model awal untuk penyebaran penyakit ini.

\section{Visualisasi Kestabilan}

Dari pembahasan pada bagian sebelumnya, telah dilihat dan dipelajari secara teoritis tentang kajian dari analisa kestabilan model penyebaran penyakit rabies. Secara sederhana proses tersebut diawali dengan model awal yang sudah ada, kemudian diturunkan hingga mendapatkan matriks Jacobian yang sesuai dengan persamaan, selanjutnya dengan titik tetap yang sudah diperoleh, akan ditemukan nilai $\lambda$ untuk menentukan arah dan bentuk kestabilan dari model penyebaran rabies tersebut.

Pada bagian ini, akan dilihat visualisasi tampilan dari kestabilan model penyebaran penyakit rabies yang akan menggunakan bantuan software MATLAB. Analisa disini akan menggunakan bantuan toolbox MATLAB pplane atau phase plane. Pplane adalah toolbox MATLAB yang kodenya ditulis oleh John Polking dari Rice University, dapat memberikan tampilan visualisasi dari sebuah sistem persamaan diferensial yang seringkali berguna untuk sketsa pada bidang vektor dimensi dua maupun bidang fase. Dengan menggunakan pplane juga akan sangat membantu dalam proses linearisasi, menentukan kestabilan titik tetap walaupun dalam beberapa contoh kasus, pplane tidak selalu akurat dalam memprediksi pusat. Tetapi dengan menggunakan bantuan pplane MATLAB, setidaknya diperoleh gambaran tentang kestabilan.

Berikut di bawah ini adalah merupakan hasil visualisasi dari pengolahan analisa model penyebaran penyakit rabies dengan menggunakan pplane MATLAB.

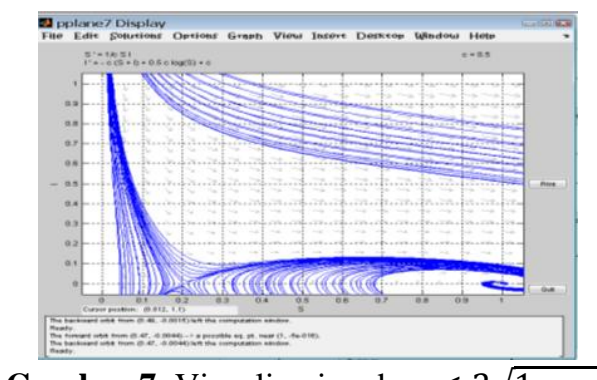

Gambar 7. Visualisasi pada $c<2 \sqrt{1-m}$

Nilai parameter $c<2 \sqrt{1-m}$ dalam penelitian ini dipilih 0,5, kestabilannya membentuk stable focus (fokus stabil) di titik $(1,0)$ seperti yang terlihat pada Gambar 7. Bentuk kestabilan ini akan tetap sama untuk setiap pemilihan nilai parameter $c<1,41422$.

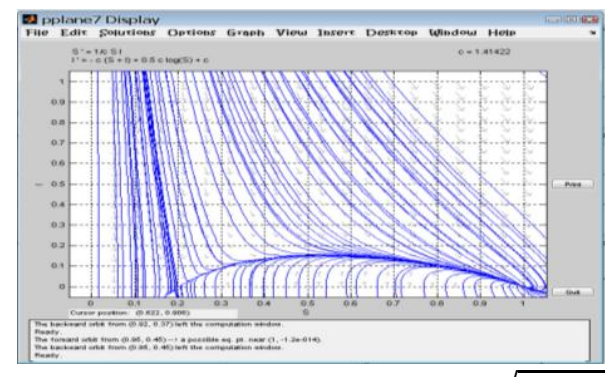

Gambar 8. Visualisasi pada $c \geq 2 \sqrt{1-m}$
Gambar 8 memberikan tampilan dari kestabilan yang dicari pada penelitian ini. Pada gambar 8 , kestabilan yang dibentuk pada nilai parameter $c \geq 2 \sqrt{1-m}$ adalah stable node (simpul stabil). Ini berarti pada titik kesetimbangan $(1,0)$, model ini akan stabil dengan mengambil nilai parameter $c \geq 1,41422$.

\section{KESIMPULAN}

Dari pembahasan pada bagian sebelumnya, maka ada dua kesimpulan yang diperoleh pada penelitian ini yaitu,

1. Model penyebaran rabies diberikan oleh $\frac{\partial S}{\partial t}=-r I S$ dan $\frac{\partial I}{\partial t}=r S I-a I+\mathrm{D} \frac{\partial^{2} I}{\partial x^{2}}$, dengan $S$ (Susceptible) adalah objek yang rentan dan I (Infectives) adalah objek yang sudah terinfeksi rabies. Kemudian setelah diturunkan, diperoleh persamaan $f(x)=S^{\prime}=\frac{1}{c} S I$, dan $g(x)=I^{\prime}=-c(S+I)+c m \ln S+c \quad$ yang nantinya membantu dalam menganalisa kestabilan penyebaran penyakit rabies.

2. Persamaan $f(x)=S^{\prime}=\frac{1}{c} S I$, dan $g(x)=I^{\prime}=$ $-c(S+I)+c m \ln S+c$, memberikan dua titik tetap di $[S(-\infty), 0]$ dan $(1,0)$. Hasil analisa kestabilan bergantung pada nilai $\lambda$ dan parameter $c$, yang memberikan analisa akhir bahwa, pada saat endemi populasi objek yang terinfeksi meningkat dan setelah endemi, populasi objek yang rentan akan kembali meningkat. Dan jika $c<2 \sqrt{1-m}$, maka model akan stabil dan penyebarannya tidak terjadi pada populasi. Sedangkan jika $c \geq 2 \sqrt{1-m}$, modelnya stabil tetapi penyebarannya terjadi dan meluas.

\section{DAFTAR PUSTAKA}

Kallen, A., Arcuri, P., and Murray, J. D. 1985. A simple model for the spatial spread and control of rabies. Journal of Theoritical Biology, 337-393

Kot, Mark. 2001. Elements of Mathematical Ecology. Cambridge University Press. USA.

Madigan, M. T., Martinko J. M., Dunlap P. V., Clark D. P. (2009). Brock Biology of Microorganisms Twelfth Edition. hlm. 1003-1005.

Steele, JH; Fernandez, J. 1991. "History of Rabies and Global Aspects", di dalam Baer, GM, The Natural History of Rabies (edisi ke-2), Boca Raton, Florida: CRC Press, Inc., hlm. 1, ISBN 0849367603

Twisleton-Wykeham-Fiennes, N. 1978. Zoonoses and the Origins and Ecology of Human Disease. Academic Press, London. 